\title{
Making urban territories more resilient to flooding by improving the resilience of their waste management network. A methodology for analysing dysfunctions in waste management networks during and after flooding. Hélène BERAUD ${ }^{1}$, Bruno BARROCA ${ }^{1}$, Damien SERRE $^{2}$, Gilles HUBERT ${ }^{1}$ \\ ${ }^{1}$ Université Paris Est - Marne la Vallée, LEESU UMR MA 102 \\ ${ }^{2}$ EIVP (École des Ingénieurs de la Ville de Paris)
}

In view of all the damage caused by flooding that has affected large numbers of regions throughout the world over the last ten years, urban areas appear to be little prepared for facing up to this type of catastrophe. Today, improving their resilience, i.e. their capacity to recover rapidly after flooding, appears to be a real issue at stake in societies' sustainable development.

Due to their organization in the form of subsystems ${ }^{1}$, the multiple aspects of their functions and the dynamics that drive them, these urban territories must be considered as complex systems ${ }^{2}$. Within these urban systems, technical networks ${ }^{3}$ are physical links between inhabitants and the actors involved, the symbolic links of belonging to the same community, to the same organized territory (Lacoste quoted by Dupuy, 1991). As supports and even objects of interactions between the different sub-systems in the urban system and with the outside environment, they supply, unify and irrigate all the constituent elements of urban territories. In this way, networks participate in organizing and regulating the system by being the vector of relations between its different constituent elements. "Physically connecting the elements in the system unifies them and creates the network's operating conditions at the same time. In the same way, it makes a certain mode of operation and evolutions in the system possible" (Dupuy, 1984). This strategic position makes networks extremely influent in the dynamics of maintaining the global urban system. In turn, they can be generators of incidents by interrupting flows or vectors in the propagation of unforeseen turns of events. Therefore, characterizing their resilience to flooding may prove to be interesting in for providing a better understanding of urban resilience.

In this context, we have decided to work on the resilience of waste management networks. Because they raise essential questions on sanitation and public health and because they often have a strong visual and psychological impact, these networks appear to be real issues at stake in crisis management. After flooding, the volume of waste generated is often significant and of a different sort (mixed, even polluted wet waste). Faced with this situation, waste management poses a real problem. What should be done with this waste? How should it be collected? Where can it be stored? How should it be processed? Who is in charge? Providing answers to these questions is all

\footnotetext{
${ }^{1}$ Sub-systems are internal components in a system.

${ }^{2}$ A complex system can be defined as "an object, which, in a given environment, endowed with given aims, exercises an activity and sees its structure develop as time goes by without it losing its one and only identity" (Le Moigne 1977). In this article, the term "system" is always to be understood in the sense of a complex system.

${ }^{3}$ In this article, the term network is understood in the sense of an urban technical network as defined by Gabriel Dupuy in "Urban planning for networks: Theories and methods", i.e. meshing that supports a service.
} 
the more strategic inasmuch as post-flood waste is the visual sign of the catastrophe. As a result, cleaning up is populations' and local actors' first reflex in order to forget what has happened, but also in order to start up again as quickly as possible. Therefore, it would appear primordial to improve waste management networks' resilience to flooding (Beraud et al., 2010).

First and foremost, improving the resilience of an organization requires understanding the way it operates in order to identify what dysfunctions it may contain. A methodology needs to be developed for this purpose, capable of analyzing a waste management network's way of operation under normal and crisis conditions. In this way, risks and potential dangers resulting from the urban system being flooded can be identified and the means of prevention for improving the waste management network's resilience to flooding can be brought out.

Choosing the right methodology is not an easy task. Numerous methods of risk analysis exist. For the most part they are of industrial origin. As a result, it is not always easy to use them for studying social systems such as urban technical networks, as these systems possess characteristics that differ considerably from industrial systems. "Multiple responsibilities with regard to the design, build, operation and maintenance of networks, separated amongst numerous actors who do not regularly communicate together and share information" are, for example, one of the particularities of risk control in an urban environment (Prost, in Blancher, 1998). As a result, the way in which networks operate may appear to be extremely complex: the diversity and involvement of actors, different scales and territories to be taken into account, the issues at stake concerning the public service mission, catastrophic consequences, that are immediate and those with important repercussions when they are interrupted, etc. This complexity makes it extremely difficult to model urban networks (Maiolini, 1992), whereas applying methods used in the world of industry requires that models are created beforehand. Therefore, there are real methodology stakes in play when transferring these methods from industrial engineering to urban engineering.

This article will present the methodology set up followed by initial results.

\section{DEFINITION OF A METHODOLOGY FOR ANALYZING A WASTE MANAGEMENT NETWORK}

Our aim is to determine the impact of flooding on waste management networks ${ }^{4}$. Therefore, first and foremost we must understand the way in which these networks operate in order to highlight their dysfunctions. As a result, in this article we will limit our analysis to waste management processes: from collecting, to processing and upgrading. Therefore waste production is not included: this is considered as being a system adjustment or modification variable that may disrupt the system's way of operation.

\footnotetext{
${ }^{4}$ This analysis takes account of all types of waste (company, household and agricultural waste, etc.).
} 


\section{A. From systematic modelling to functional analysis: a study of the way in which waste management networks operate}

Studying the way a waste management network operates requires for it be considered as a complex system. It is, in fact, an object formed by elements or sub-systems organized for one purpose, an ultimate goal ("managing waste"), and which are in constant interrelation between each other and with the outside environment (the urban system, the wider environment). With this systemic conception of a waste management network not only a global analysis of the object can be made, highlighting the interdependencies and interrelations that structure it, but evolutions, and dynamics that model the network, can also be thought out.

Understanding how a system operates requires for its structure, its environment and its functions ${ }^{5}$ to be analysed, as well as its operating conditions (Villemeur, 1988). This is all made possible by the use of a functional analysis. This method "enables us to understand the way in which the system under study operates and to make a synthetic description of it: it(the method) defines its limits, its environment and its structure and it discovers the functions that are provided" (Peyras, 2002). As such, using this method enables the principles of operation of the waste management system to be established and its mechanisms to be determined.

Several methods of functional analysis exist. We have decided to use the APTE method (Application aux Techniques d'Entreprise) frequently used for analyzing organizations. It has the advantage of making a functional analysis - a description of the functions fulfilled by the system - together with a morphological analysis - a description of the system (components, environment and relations).

The APTE method is carried out in two phases:

- An external functional analysis shows why the system exists, it shows what purpose it serves and it clearly reveals its main functions, i.e. the functions for which the system was created;

- An internal functional analysis enables the internal operation of the system to be understood (the morphological analysis) and it reveals the functions that enable the system to attain its objectives.

This method is based on the use of two tools: the functional block diagram and the functional analysis chart (Peyras, 2002). The first tool is a representation of the system, its outside environments and the interactions that irrigate it. The second tool results from the block diagram. It presents the system's different functions.

The analysis of the way in which the waste management network operates will be carried out for each crisis phase: in the pre-crisis period ${ }^{6}$, in the crisis period ${ }^{7}$, and in the post-crisis period ${ }^{8}$. This will show how functions evolve due to flooding.

Once this operation has been carried out, any potential dysfunctions in the network will become apparent.

\footnotetext{
${ }^{5}$ In this case the term function is defined in the sense of standard NF X50-150, i.e. the action of a product or one of its constituents expressed in terms of its final purpose.

${ }^{6}$ Pre-crisis: flooding is announced, but water-levels have not risen yet.

${ }^{7}$ Crisis: flooding has arrived.

${ }^{8}$ Post-crisis: flood levels have dropped, but the region's operating system has not returned to normal as yet.
} 


\section{B. Revealing dysfunctions in a waste management network}

The study of potential dysfunctions in the waste management system will be carried out with the help of the FMECA method (Failure Modes, Effects and Criticality analysis), which is one of the operational safety methods most used in industry and, over the past few years, in civil engineering. An inductive method for analyzing potential failures in a system, it is generally carried out in three main phases: (1) Breaking down the system by means of a functional analysis, (2) Identifying failure modes ${ }^{9}$, (3) Describing the effects of the failure modes that have appeared in the system. Then, a preventive action strategy can be defined to enable the waste management system to maintain active during crisis and post-crisis periods.

In an 'operational safety' approach, this method generally covers three stages carried out one after the other: the product FMECA, whose objective is to check that the system carries out its functions correctly in the operating phase; the process FMECA that examines whether the product obtained is compliant with what is produced; and the resource FMECA which investigates the resources needing to be implemented (Peyras, 2002). These phases will not all be required for our case study. As we only wish to identify potential dysfunctions in the waste management network during flooding, our analysis will only cover its operating cycle. For this reason, we will only be applying the product FMECA.

Our initial results are described below. They concern the functional analysis of the waste management network.

\section{INITIAL RESULTS: FUNCTIONAL ANALYSIS OF THE WASTE MANAGEMENT NETWORK}

\section{A. Structural analysis of the waste management network}

As we have defined above, we are limiting our study to cover solely the management processes that correspond to the domains belonging to the different system processes. The waste management network is, in fact, composed of a "Waste management process" system which is broken down into five sub-systems that correspond to the five stages in waste management: Collecting, storing, transporting, treating and upgrading. This process system is related to elements from the outside environment through which and for which it exists: waste, producers of waste, the society, rule-making authorities (State, European Community, State decentralized services, etc.), organizing authorities (Territorial communities, producer associations, etc.), sensitive environments (water, soil, air, biodiversity, etc.), aggressive environments (natural catastrophes, bad weather, climate change, etc.), networks, companies that use secondary raw materials and the world market.

\section{B. External functional analysis}

On the basis of this description of the system, we must then define why the system exists. To do this, its main functions and its constraint functions need to be defined.

\footnotetext{
${ }^{9}$ Failure mode: The way in which the failure appears
} 
Main functions (MF) correspond to the relations created by the organization between certain of its constituent elements and the outside environment. They express the system's purpose. As for constraint functions (CF) they express the requirements of an element from outside the system made on the system itself.

These functions will be defined by studying the relations that exist between the system and outside constituents. The diagram below presents these relations.

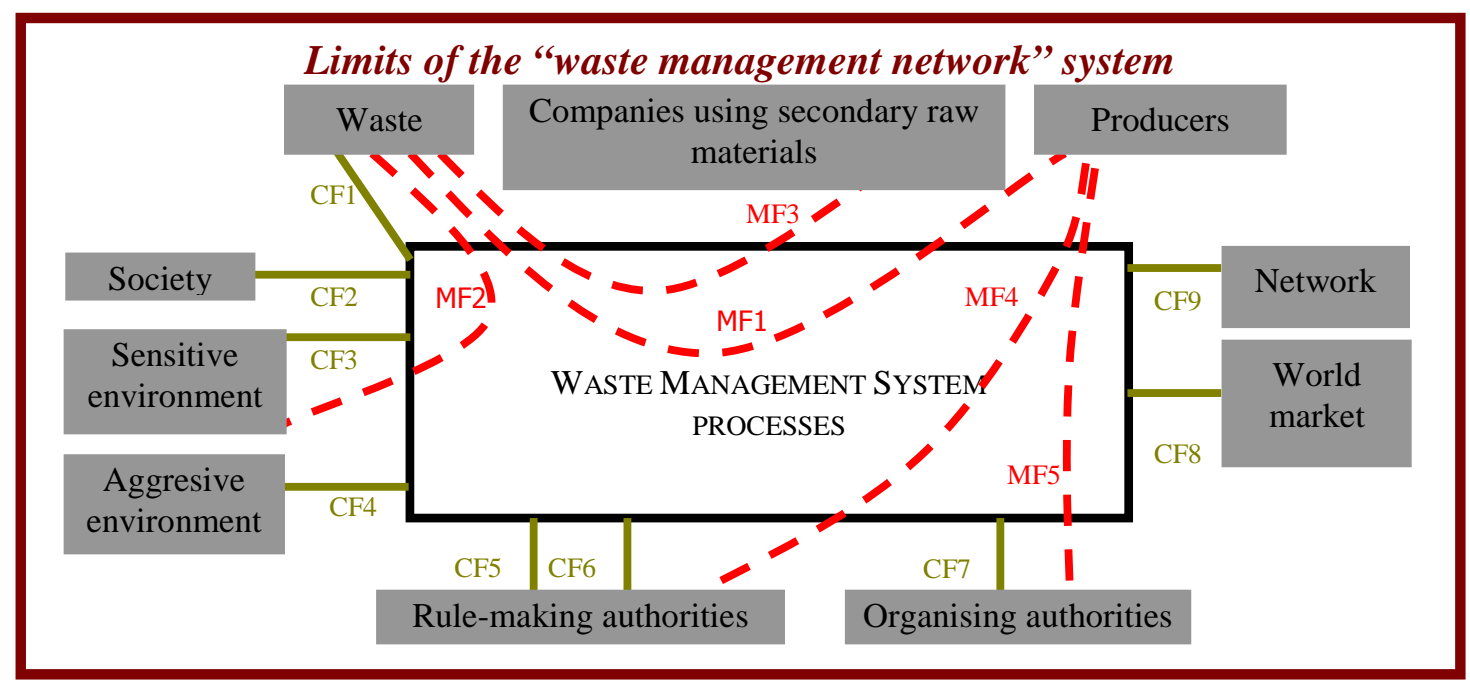

Figure 1: External functional block diagram of the "waste management network" system

Five main functions and nine constraint functions have been defined. However, these functions may be brought together under three denominations that correspond to the major missions of a waste management process.

1. Managing waste in a way adapted to the type of flow (MF1:Managing waste generated by producers, MF3: Upgrading waste in the form of new products or new raw materials, MF5: Enabling the organizing authority to make waste producers pay for treating their waste, CF2: Meeting society's expectations in terms of sanitation, health and safety, CF6: Meeting control organization requirements, CF7: Being remunerated by the organizing authority, CFF: Taking account of world market evolutions for choosing the system process, $\boldsymbol{C F 9}$ : Operating by means of infrastructures and networks),

2. Limiting impacts on the environment (MF2: Limiting effects of waste on the environment, MF4: Inciting producers to reduce the waste they generate by means of different standardization and rule-making tools, MF5: Enabling the organizing authority to make producers of waste pay for wastetreatment, CF3: Respecting sensitive environment and reducing pollution of water, earth and air in view of regulations in force, CF5: Complying with regulations, CF6: Meeting control organization requirements),

3. Maintaining waste management in operation (continuity of service, obligations in terms of sanitation and public safety) (CF2: Meeting society's expectations in terms of sanitation, health and safety, CF4: Inciting producers to reduce the waste they generate by means of different standardization and rule-making tools).

These three missions are the reasons why waste management system processes, and therefore whole networks, exist. For this reason, the way the latter operates internally must enable these main missions to be carried out successfully.

\section{Internal functional analysis}

Characterisation of the internal operation of a waste management network necessitates defining the role of every component inside the system i.e. determining the different 
relations that connect the components in the system to each other and to the outside environment. These different relations define the so-called design functions that enable the system to execute the missions for which it was created.

The diagram below represents these relations.

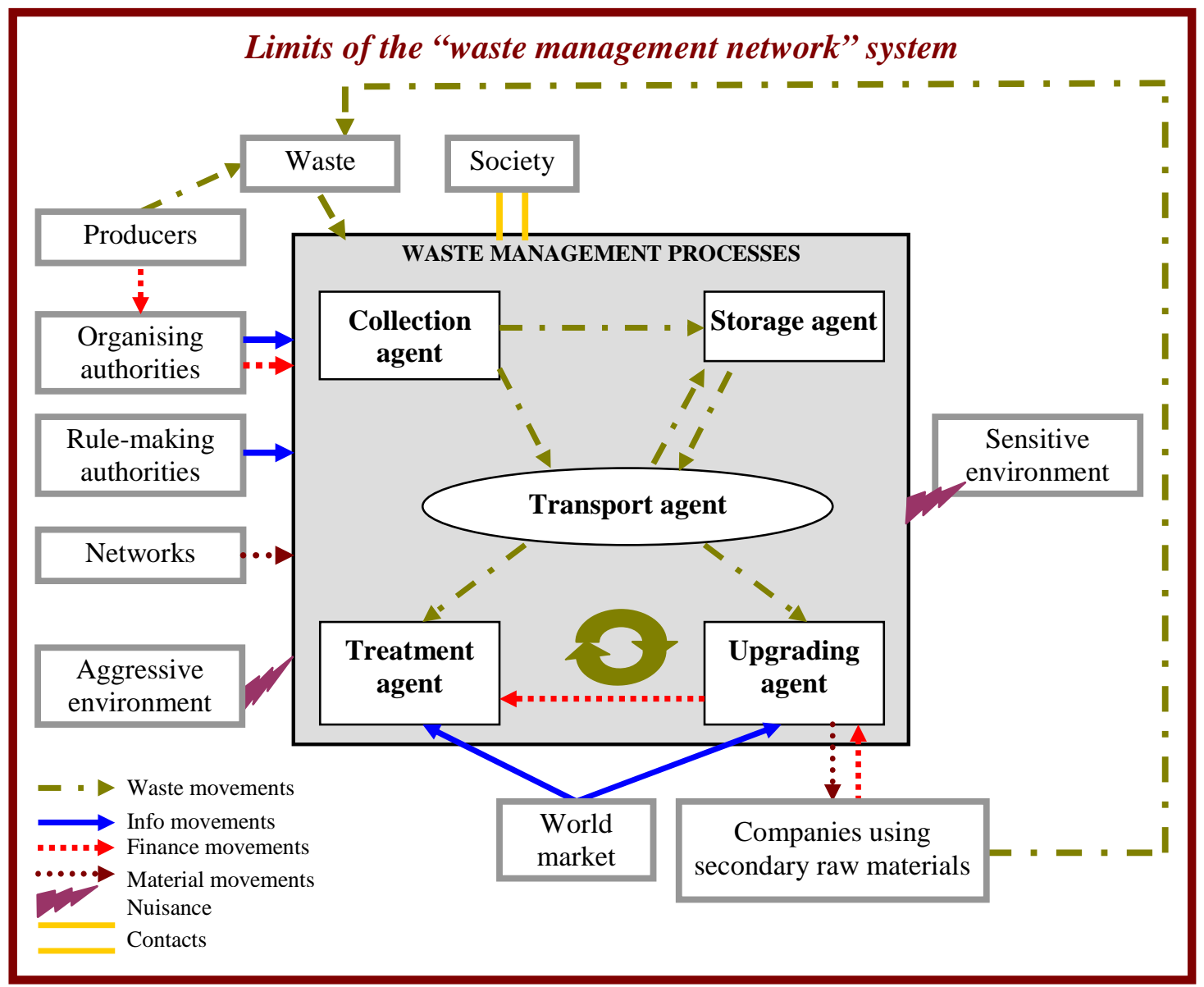

Figure 2: Internal functional block diagram of the "waste management network" system.

This work on defining relations and then defining functions, was carried out in normal operating periods and in flood periods. The following table is an extract of the results that we obtained. It presents the functions carried out by the collecting agent to meet the three main missions of the global system (managing waste, limiting impacts on the environment and maintaining activity) in normal operating and flood conditions.

Table 1: Extract of the internal functional analysis table: Collection agent analysis

\begin{tabular}{|c|c|c|c|c|}
\hline \multirow{2}{*}{$\begin{array}{c}\text { MAIN } \\
\text { MISSIONS }\end{array}$} & \multirow{2}{*}{$\begin{array}{l}\text { DESIGN FUNCTIONS } \\
\text { NORMAL CONDITIONS }\end{array}$} & \multicolumn{3}{|c|}{$\begin{array}{l}\text { DESIGN FUNCTIONS } \\
\text { FLOOD CONDITIONS }\end{array}$} \\
\hline & & PRE-CRISIS & CRISIS & POST-CRISIS \\
\hline \multirow{3}{*}{ 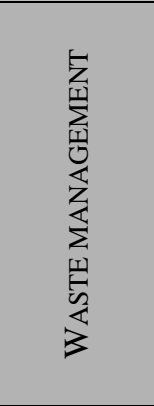 } & Collecting waste & Collecting waste & $\begin{array}{l}\text { Collecting waste in } \\
\text { the flooded zone }\end{array}$ & $\begin{array}{l}\text { Collecting normal } \\
\text { waste and post-flood } \\
\text { waste }\end{array}$ \\
\hline & $\begin{array}{l}\text { Centralising waste } \\
\text { before transport to the } \\
\text { point of treatment }\end{array}$ & $\begin{array}{l}\text { Centralising waste } \\
\text { before transport to } \\
\text { its point of } \\
\text { treatment }\end{array}$ & $\begin{array}{l}\text { Centralising waste } \\
\text { before transport to } \\
\text { its point of } \\
\text { treatment }\end{array}$ & $\begin{array}{l}\text { Centralising waste } \\
\text { before transport to its } \\
\text { point of treatment }\end{array}$ \\
\hline & $\begin{array}{l}\text { Receiving } \\
\text { remuneration for } \\
\text { services provided }\end{array}$ & $\begin{array}{l}\text { Receiving } \\
\text { remuneration for } \\
\text { services provided }\end{array}$ & $\begin{array}{l}\text { Receiving } \\
\text { remuneration for } \\
\text { services provided }\end{array}$ & $\begin{array}{l}\text { Receiving } \\
\text { remuneration for } \\
\text { services provided }\end{array}$ \\
\hline
\end{tabular}




\begin{tabular}{|c|c|c|c|c|}
\hline & $\begin{array}{l}\text { Defining collection } \\
\text { rounds depending on } \\
\text { waste flows }\end{array}$ & $\begin{array}{l}\text { Anticipating } \\
\text { evolutions in waste } \\
\text { movement with the } \\
\text { arrival of flooding }\end{array}$ & $\begin{array}{l}\text { Reorganising } \\
\text { collection rounds }\end{array}$ & $\begin{array}{l}\text { Reorganising } \\
\text { collection rounds } \\
\text { depending on new } \\
\text { missions to be carried } \\
\text { out. }\end{array}$ \\
\hline & & & $\begin{array}{l}\text { Facing up to } \\
\text { possible breaks in } \\
\text { networks }\end{array}$ & $\begin{array}{l}\text { Managing evolutions } \\
\text { in waste flows }\end{array}$ \\
\hline & & & $\begin{array}{l}\text { Managing } \\
\text { evolutions in waste } \\
\text { movements }\end{array}$ & $\begin{array}{l}\text { Informing on post- } \\
\text { flood waste collection } \\
\text { conditions }\end{array}$ \\
\hline \multirow{4}{*}{ 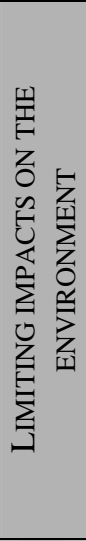 } & $\begin{array}{l}\text { Complying with } \\
\text { regulations }\end{array}$ & $\begin{array}{l}\text { Complying with } \\
\text { regulations }\end{array}$ & $\begin{array}{l}\text { Complying with } \\
\text { regulations }\end{array}$ & $\begin{array}{l}\text { Complying with } \\
\text { regulations }\end{array}$ \\
\hline & $\begin{array}{l}\text { Quantifying waste } \\
\text { collected and } \\
\text { invoicing it to } \\
\text { producers }\end{array}$ & $\begin{array}{l}\text { Quantifying waste } \\
\text { collected and } \\
\text { invoicing it to } \\
\text { producers }\end{array}$ & $\begin{array}{l}\text { Quantifying waste } \\
\text { collected and } \\
\text { invoicing it to } \\
\text { producers }\end{array}$ & $\begin{array}{l}\text { Quantifying waste } \\
\text { collected and } \\
\text { invoicing it to } \\
\text { producers }\end{array}$ \\
\hline & & & & $\begin{array}{l}\text { Cleaning zones } \\
\text { impacted by flooding } \\
\text { as rapidly as possible. }\end{array}$ \\
\hline & & & & $\begin{array}{l}\text { Remaining in contact } \\
\text { with services in } \\
\text { charge of health } \\
\text { control }\end{array}$ \\
\hline \multirow{3}{*}{ 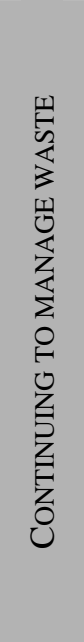 } & $\begin{array}{l}\text { Honouring } \\
\text { commitments to } \\
\text { maintain activities }\end{array}$ & $\begin{array}{l}\text { Reorganising } \\
\text { rounds }\end{array}$ & $\begin{array}{l}\text { Remaining in } \\
\text { contact with the } \\
\text { different partners in } \\
\text { waste management } \\
\text { during evolutions in } \\
\text { the crisis situation. }\end{array}$ & $\begin{array}{l}\text { Remaining in contact } \\
\text { with treatment and } \\
\text { transport } \\
\text { organisations that will } \\
\text { have to take action } \\
\text { afterwards. }\end{array}$ \\
\hline & $\begin{array}{l}\text { Remaining in regular } \\
\text { contact with partners, } \\
\text { organising / } \\
\text { regulating authorities } \\
\text { so as to maintain } \\
\text { activities. }\end{array}$ & $\begin{array}{l}\text { Informing } \\
\text { producers in flood } \\
\text { areas on the actions } \\
\text { to take for reducing } \\
\text { post-flood waste }\end{array}$ & $\begin{array}{l}\text { Keeping the } \\
\text { organising authority } \\
\text { informed of } \\
\text { evolutions in } \\
\text { activity. }\end{array}$ & $\begin{array}{l}\text { Keeping the } \\
\text { organising authority } \\
\text { informed of } \\
\text { evolutions in activity. }\end{array}$ \\
\hline & & $\begin{array}{l}\text { Keeping the } \\
\text { organising authority } \\
\text { informed of } \\
\text { changes in activity. }\end{array}$ & & \\
\hline
\end{tabular}

The work on analysing the way in which the waste management network operates, presented here via the waste collection agent, highlights the large number of functions that elements in the system need to carry out so that the system can fulfil its three main missions (managing waste, limiting impacts on the environment and maintaining services), at the three different periods in the crisis. It must be remembered that, when there is a flood, the actors involved must deal with new missions. As a result, as soon as a rise in water levels is announced, the collection agent must slightly modify the way it operates in order to take account of the forthcoming flood. It must be remembered that the agent's duties to maintain public services oblige it to pursue its missions during crisis and post-crisis periods. Therefore, it has to anticipate and prevent dysfunctions. During flood periods, if waste collection is stopped for flood areas, it is maintained outside flood areas. It is for this reason that the collection agent's missions are 
modified. In the post-crisis period, the collection agent must also handle new missions that have appeared with the production of post-flood waste. Therefore, solutions must be found urgently for collecting very considerable quantities of new waste, whilst continuing to collect normal waste at the same time.

\section{CONCLUSION}

As we have demonstrated above, improving the resilience of waste management networks to flooding passes by preventing any dysfunctions in the network. To do this, an analysis must be carried out of the way in which the waste management network operates, followed by an inventory of any possible dysfunctions and their characterisation. Our research has shown that, despite the numerous adaptations required, risk analysis methods coming from industry prove to be the most suitable for studying a system as complex as a waste management network. As a result, the functional analysis method was chosen for showing how this complex system operates. Then, applying the FMECA method reveals any potential dysfunctions.

The first results presented here on the scale of sub-systems in the process system reveal the appearance of new functions during flood periods. These new functions, which are essential for enabling the system to fulfil its three main missions (managing waste, limiting impacts on the environment and maintaining services), require considerable human, technical and financial resources. This initial analysis is not sufficient for measuring these resources. It must be more detailed, on a smaller scale, i.e. within each sub-system (collection, storage, treatment, etc.) so as to be able to assess the way the system operates on a scale that can be used for applying preventive measures. The dysfunction analysis phase, which will enable us to list potential failures in the way the system operates, can then be applied on these two levels (sub-systems of the process system and components in the sub-system of the process system).

\section{BIBLIOGRAPHY}

BERAUD H., BARROCA B., and HUBERT G. (2010), Flood resilience urban territories Geophysical Research Abstracts, Vol. 12, EGU2010-7875, 2010 EGU General Assembly 2010

BLANCHER P. (Dir.) (1998), Risques et réseaux techniques urbains, Lyon, CERTU, 169 p.

DUPUY G. (1984), Villes, systèmes et réseaux : le rôle historique des techniques urbaines, Réseaux, vol. 2, n 4,1984, p. $3-23$

DUPUY G. (1991), L'urbanisme des réseaux : théories et méthodes, Paris, A. Colin, 198 p.

LE MOIGNE J.-L. (1977), La théorie du système général. Théorie de la modélisation., Paris, PUF, 258 p. MAIOLINI J.-L. (1992), Sûreté de fonctionnement des réseaux urbains. Deux études de cas : les réseaux d'alimentation en eau potable et les galeries techniques visitables, Projet de fin d'études, sous la direction de OLIVIER D., ENPC, 41 p + annexes.

PEYRAS L. (2002), Diagnostic et analyse de risques liés au vieillissement des barrages. Développement de méthodes d'aide à l'expertise, Thèse, sous la direction de VERGNE A., Aix-Marseille II, 199 p.

VILLEMEUR A. (1988), Sûreté de fonctionnement des systèmes industriels. Fiabilité - Facteurs humains - Informatisation, Paris, Eyrolles, 795 p. 